\title{
Ouabain-evoked Norepinephrine Release from Intact Rat Sympathetic Neurons: Evidence for Carrier-mediated Release ${ }^{1}$
}

\author{
KATHLEEN J. SWEADNER
}

Neurosurgical Research, Massachusetts General Hospital, Boston, Massachusetts 02114 and Department of Physiology, Harvard Medical School, Boston, Massachusetts 02115

\begin{abstract}
Inhibition of the Na,K-ATPase is known to cause transmitter release from many neurons. The mechanism of $\left[{ }^{3} \mathrm{H}\right]$ norepinephrine release was examined in primary cultures of sympathetic neurons. Ouabain caused $\left[{ }^{3} \mathrm{H}\right]$ norepinephrine release at concentrations that produced 80 to $90 \%$ inhibition of Na,K-ATPase activity. The effect of ouabain was compared with the effects of high $\mathrm{K}^{+}$and the $\mathrm{Ca}^{2+}$ ionophore A23187. $\left[{ }^{3} \mathrm{H}\right]$ Norepinephrine release elicited by depolarization with high extracellular $\mathrm{K}^{+}$was dependent on extracellular $\mathrm{Ca}^{2+}$, was unaffected by tetrodotoxin, was potentiated by reducing extracellular $\mathrm{Na}^{+}$, and was potentiated by the norepinephrine uptake inhibitor desipramine. These are the results expected if high $\mathrm{K}^{+}$causes release by exocytosis, and if blockade of the $\mathrm{Na}^{+}$-dependent norepinephrine uptake system increases the net measurable release of the transmitter. The $\mathrm{Ca}^{2+}$ ionophore A23187 caused $\left[{ }^{3} \mathrm{H}\right]$ norepinephrine release that was not dependent on extracellular $\mathrm{Ca}^{2+}$ but which was like the release elicited by high $\mathrm{K}^{+}$in other respects. Release elicited by ouabain was independent of extracellular $\mathrm{Ca}^{2+}$, was delayed for several hours by tetrodotoxin, was inhibited by reducing the concentration of extracellular $\mathrm{Na}^{+}$, and was inhibited by desipramine. These results suggest that the measured increase in transmitter release is secondary to a rise in the concentration of intracellular $\mathrm{Na}^{+}$. The data are consistent with the hypothesis that at high levels of pump inhibition, ouabain elicits nonvesicular $\left[{ }^{3} \mathrm{H}\right]$ norepinephrine release through reversal of the $\mathrm{Na}^{+}$-dependent plasma membrane carrier.
\end{abstract}

Birks (1963) first investigated the effect of inhibition of the $\mathrm{Na}^{+}$ pump on neurotransmitter release, after pointing out that the changes in intracellular ion concentrations produced are similar to those that would be expected to accompany repetitive nerve activity. Since then, a number of investigators have confirmed that cardiac glycosides elicit transmitter release in the autonomic nervous system, in the brain, at the neuromuscular junction, and in the adrenal medulla (see Powis, 1983, for review). The mechanism remains controversial, however. Inhibition of the Na,K-ATPase could lead to depolarization

Received October 11, 1984; Revised February 13, 1985;

Accepted February 15, 1985

${ }^{1}$ This work was supported by National Institutes of Health Grant NS 18233. K. J. S. is an Established Investigator of the American Heart Association and a Research Fellow of the Alfred P. Sloan Foundation. Ms. Heather Shutt gave invaluable assistance in the maintenance of cultures and in the execution of experiments. Desipramine was generously provided by Dr. W. J. Hudak, Merrell Dow Laboratories, Cincinnati, Ohio. of the neuron, followed by $\mathrm{Ca}^{2+}$ influx and transmitter release by exocytosis (Banks, 1967). It could also lead indirectly to a rise in intracellular $\mathrm{Ca}^{2+}$, through mobilization of intracellular $\mathrm{Ca}^{2+}$ stores (Baker and Crawford, 1975), through $\mathrm{Ca}^{2+}$ exchange for intracellular $\mathrm{Na}^{+}$(Nakazato et al., 1978), or through inhibition of $\mathrm{Ca}^{2+}$ efflux (Pocock, 1983a, b), which again would permit transmitter release by exocytosis. Raiteri and Levi (1978) have proposed that an increase in intracellular $\mathrm{Na}^{+}$permits the nonvesicular efflux of transmitters by reversal of $\mathrm{Na}^{+}$-dependent plasma membrane carriers. Vizi et al. (1982) argue that inhibition of the Na,K-ATPase somehow direclly results in transmitter release through unidentified membrane pathways, independent of changes in intracellular ion concentrations.

The fact that evidence has been presented in support of all of these models suggests that there is considerable heterogeneity in experimental preparations, such as in the properties of membrane pumps and channels. There are two molecular forms of the $\mathrm{Na}, \mathrm{K}$ ATPase, for example, which have different biochemical properties and different affinities for the cardiac glycosides (Sweadner, 1979). The two forms can be expressed in different kinds of cells (Specht and Sweadner, 1984), and it is not known which form is expressed in preparations used previously to investigate the role of the $\mathrm{Na}, \mathrm{K}$ ATPase in transmitter release. In addition, the excision, slicing, or homogenization of a tissue may affect membrane leakiness, which could affect the steady-state metabolism of ions. It would be advantageous to study cells which have not becn mechanically disturbed and in which the Na,K-ATPase has been identified.

In the experiments described here, the controversy has been addressed by examining the mechanism of ouabain-evoked release of $\left[{ }^{3} \mathrm{H}\right]$ norepinephrine from primary cultures of sympathetic neurons, which express the form of the Na,K-ATPase with a low affinity for cardiac glycosides (Sweadner, 1979). Sympathetic neurons from neonatal rats can be maintained in primary cell culture in the virtual absence of other cell types, where they express the physiological, biochemical, and morphological characteristics of such neurons in the adult (Landis, 1976; O'Lague et al., 1978; Patterson, 1978). The cultures release endogenous norepinephrine when stimulated electrically (Furshpan et al., 1976). They also accumulate and store exogenous $\left[{ }^{3} \mathrm{H}\right]$ norepinephrine in a reserpine-sensitive pool and release it when treated with agents that are thought to elicit the exocytosis of synaptic vesicles, such as elevated extracellular $\mathrm{K}^{+}$ (Patterson et al., 1976) and black widow spider venom (Sweadner, 1983). Such cultures are favorable for the study of the ionic basis of neurotransmitter release because the cells are intact, and because the uptake and efflux of ions from other cell types is eliminated.

\section{Materials and Methods}

Cell cultures. Primary cultures of postmitotic sympathetic neurons from the superior cervical ganglion of the newborn CD rat (Charles River Breeding Laboratories, Wilmington, MA) were prepared and maintained as described proviously by Hawrot and Patterson (1979), in medium containing $5.4 \mathrm{~mm} \mathrm{~K}^{+}$ and no conditioned medium. Cells were plated in 8-mm-diameter wells formed 
by boring holes in 35-mm Petri dishes and sealing plastic coverslips to the holes with wax. Cells (500 to $1000 /$ well) were plated on a substratum of dried collagen, and the cultures were maintained in bicarbonate-containing medium in the presence of nerve growth factor (the gift of A. Doupe, Harvard Medical School) for 3 to 6 weeks before use. Non-neuronal cells were eliminated during the first week after plating by treatment with arabinosylcytosine. All solutions used on living cultures were prepared in deionized and glass-distilled water, using only disposable, sterile tissue culture flasks and pipettes to avoid contamination with detergents and other chemicals.

$\left[{ }^{3} \mathrm{H}\right]$ Norepinephrine uptake and release. Norepinephrine release was assessed by measuring the release of tritium from cultures which had accumulated exogenous $\left[{ }^{3} \mathrm{H}\right]$ norepinephrine. Cells were allowed to accumulate $\mathrm{L}-\left[2,5,6-\left[{ }^{3} \mathrm{H}\right]\right.$ norepinephrine or $\mathrm{DL}-\left[7-{ }^{3} \mathrm{H}\right]$ norepinephrine (New England Nuclear, Boston, MA) during a 1 -hr incubation with $10^{-6} \mathrm{M}$ exogenous $\left[{ }^{3} \mathrm{H}\right]$ norepinephrine (specific activity, 10.8 to $54.8 \mathrm{Ci} / \mathrm{mmol}$ ) in $1 \mathrm{ml}$ of culture medium. Cultures of sympathetic neurons containing 500 to 1000 cells typically accumulated 1 to $2 \%$ of the $\left[{ }^{3} \mathrm{H}\right]$ norepinephrine available to them during a 1 -hr preincubation. The cultures were then washed three times with minimal salts solution (140 mM NaCl, $5.4 \mathrm{~mm} \mathrm{KCl}, 1.0 \mathrm{mM} \mathrm{MgCl}, 1.2 \mathrm{~mm}$ $\mathrm{CaCl}_{2}, 10 \mathrm{~mm}$ glucose, and $1.5 \mathrm{~mm}$ HEPES/Tris buffer, $\mathrm{pH} 7.0$ ) and were preincubated in $50 \mu \mathrm{l}$ of minimal salts solution for $30 \mathrm{~min}$ to $1 \mathrm{hr}$ to allow the deamination and excretion of cytoplasmic $\left[{ }^{3} \mathrm{H}\right]$ norepinephrine. Patterson et al. (1976) found that under these conditions the majority of $\left[{ }^{3} \mathrm{H}\right]$ norepinephrine remaining in the cells is reserpine sensitive and is stored in a particulate fraction, presumably the synaptic vesicles. As reported previously (Burton and Bunge, 1975: Patterson et al., 1976), uptake of exogenous $\left[{ }^{3} \mathrm{H}\right]$ norepinephrine was blocked by $10^{-5} \mathrm{M}$ desipramine, and the stored label was released upon treating the cells with $2 \times 10^{-6} \mathrm{M}$ reserpine or $10^{-3} \mathrm{M}$ tyramine (data not shown). This is consistent with the established evidence that there is a desipramine-sensitive plasma membrane carrier for norepinephrine (lversen, 1975), as well as reserpine-sensitive, tyramine-displaceable storage of the norepinephrine in a synaptic vesicle pool.

After the neurons were loaded with exogenous $\left[{ }^{3} \mathrm{H}\right]$ norepinephrine, the release of tritium was followed by changing the minimal salts solution every hour and measuring the radioactivity released and that remaining in the cells at the end of the experiment. Cultures were dissolved in $1 \%$ sodium dodecyl sulfate, and radioactivity was counted by liquid scintillation in Ultrafluor (National Diagnostics, Somerville, NJ). The data are displayed as the log of the total radioactivity remaining in the cells versus time; when release occurs as a simple exponential, this permits expression of the rate of release as a half-time and corrects for the depletion of labeled intracellular stores. The absolute rates of release, both basal and stimulated, varied between platings but were very reproducible when cultures from the same plating were compared. The experiments shown are representative results obtained with cultures from 14 different platings, and all experiments were repeated with cultures from at least two platings.

Release experiments were performed in minimal salts solution instead of complete medium to avoid the fluctuations of $\mathrm{pH}$ attendant on using bicarbonate-containing media. Control experiments performed in complete culture medium, including nerve growth factor, serum, and bicarbonate, gave the same results as experiments performed in minimal salts solution with glucose.

Assay of $\mathrm{Na}, \mathrm{K}-\mathrm{Al}$ Pase inhibition. Because the inhibition of the $\mathrm{Na}, \mathrm{K}$. ATPase by cardiac glycosides is slow, a continuous spectrophotometric assay was used to monitor the rate of hydrolysis of ATP so that equilibrium inhibition values could be measured. ATP hydrolysis was coupled to the oxidation of nicotinamide adenine dinucleotide $(\mathrm{NADH})$ using pyruvate kinase and phosphoenolpyrivate to regenerate ATP and prodice pyrıvate, and lactate dehydrogenase to reduce pyruvate and oxidize NADH (Pullman et al. 1960). The reaction was monitored at $340 \mathrm{~nm}$ in a Perkin-Eimer Lambda* 3 spectrophotomcter cquipped with a thermoelectric cell holder set for $37^{\circ} \mathrm{C}$ Hydrolysis in the absence of cardiac glycoside was linear with time provided that vanadium-free ATP was used (grade I ATP from Sigma Chemical Co., St. Louis, MO). ATP hydrolysis in the presence of cardiac glycoside declined slowly with time but reached a steady state within, at most, 20 to $30 \mathrm{~min}$. Because of the limited quantities of sympathetic neurons available, membranes prepared from cultured rat brain non-neuronal cells (Sweadner, 1979) were substituted in these experiments. Previous work indicated that cultured sympathetic neurons and glia express the same form of the Na,K-ATPase by the criteria of cardiac glycoside affinity and subunit electrophoretic mobility (Sweadner, 1979), and more recent evidence has been obtained that they are antigenically cross-reactive as well (K. J. Sweadner and R. C. Gilkeson, manuscript in preparation). The concentrations of $\mathrm{NaCl}$ and $\mathrm{KCl}$ were those used in the minimal salts solution. $\mathrm{CaCl}_{2}$ was omitted, and choline chloride was added as appropriate. ATP and $\mathrm{MgCl}_{2}$ were both $3 \mathrm{mM}$, and the buffer was $30 \mathrm{~mm}$ HEPES/Tris, $\mathrm{pH} 7.2$
Materials. The $\mathrm{Ca}^{2+}$ ionophore A23187 was obtained from CalbiochemBehring (La Jolla, CA). A stock solution prepared in dimethyl formamide was found to lose activity even when protected from light and stored at $-20^{\circ} \mathrm{C}$; therefore, a fresh solution was prepared for each experiment. Desipramine was obtained from Merrell Dow Pharmaceuticals Inc. (Cincinnati, OH). Ouabain, strophanthidin, veratridine, tetrodotoxin, pargyline, reserpine, ATP, phosphoenolpyruvate, $\mathrm{NADH}$, lactate dehydrogenase, and pyruvate kinase were obtained from Sigma Chemical Co. (St. Louis, MO)

\section{Results}

Release elicited by inhibition of the Na,K-ATPase. The concentration of ouabain required to elicit $\left[{ }^{3} \mathrm{H}\right]$ norepinephrine release from sympathetic neurons was compared with that required to inhibit the $\mathrm{Na}, \mathrm{K}$-ATPase in vitro to estimate what fraction of pump activity must be inactivated tor a measurable effect (Fig. 1). The rate of release is expressed as the ratio of the half-time in untreated cells to the half-time in treated cells, to correct for plating-to-plating variations (up to 2-fold) in the basal rate of release. The activity of the enzyme was assayed in vitro in a reaction mixture that simulated the ionic conditions in the extracellular medium except for the presence of 3 $\mathrm{mm} \mathrm{ATP}$ and $3 \mathrm{mM} \mathrm{MgCl}_{2}$, and the absence of $1.2 \mathrm{mM} \mathrm{CaCl} . \mathrm{Na}^{+}$ and $\mathrm{K}^{+}$concentrations typical of the extracellular environment were used instead of intracellular concentrations because the affinity of the ouabain-binding site, which faces the extracellular medium, is known to be affected by extracellular $K^{\prime}$ (Schwartz et al., 1975). Ouabain inhibited the Na,K-ATPase with a $K_{0.5}$ of $3 \times 10^{-5} \mathrm{M}$, whereas ouabain- or strophanthidin-elicited norepinephrine release had a much steeper concentration dependence. Accelerated release was seen only after a threshold was exceeded, when $80 \%$ or more of the Na,K-ATPase was inhibited.

Ouabain had no effect on norepinephrine release at concentrations less than $10^{-3} \mathrm{M}$, but at exactly $10^{-3} \mathrm{M}$ it was observed in different replicate experiments to have three different kinds of effects: (1) no effect, (2) a rate of release intermediate between the control and that seen at $3 \times 10^{-3} \mathrm{M}$ ouabain, and (3) the effect illustrated in Figure 2, where release occurred at the control rate for

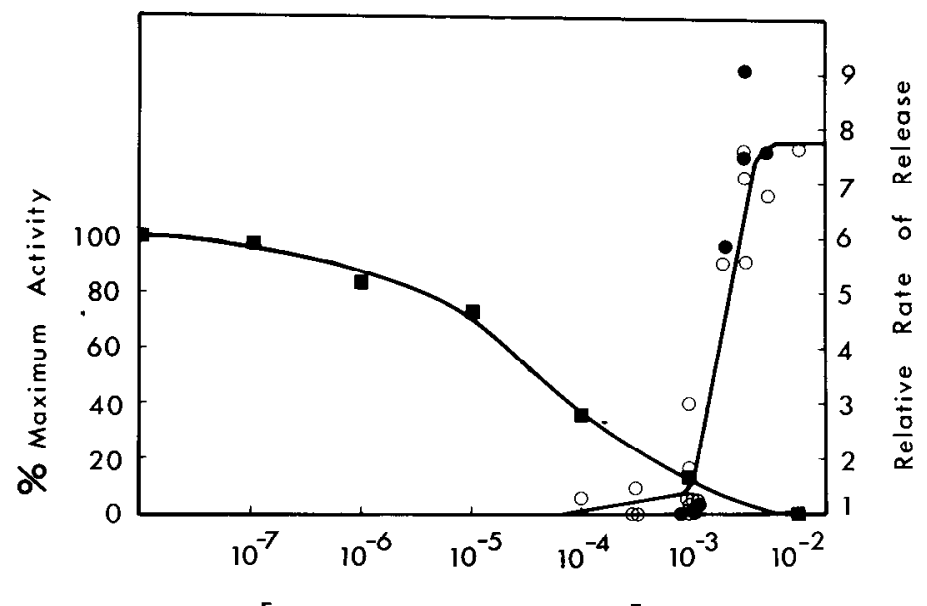

[Ouabain or Strophanthidin]. $M$

Figure 1. Concentration dependence for the inhibition of the Na,K-ATPase by ouabain, and for the stimulation of norepinephrine release by ouabain or its congener, strophanthidin. Inhibition of the Na,K-ATPase was measured in a membrane preparation obtained from cultured rat brain glia, which express the same form of the Na,K-ATPase that is expressed by cultured rat sympathetic neurons. Ouabain-insensitive ATPase activity, which was approximately $50 \%$ of the total ATPase activity, was subtracted from the data shown. ouabain-sensitive ATPase activity. The relative rate of norepinephrine release is expressed as the ratio of the half-time of release in the presence of ouabain $(O)$ or strophanthidin $(\bullet)$ to the half-time of release in its absence. Each point is the result of a separate experiment such as those illustrated in the other figures. The majority of the radioactivity released in control cultures is actually in the form of metabolites of norepinephrine (data not shown). Therefore, the relative rates of release in the presence and absence of ouabain or strophanthidin are likely to be minimum estimates. 


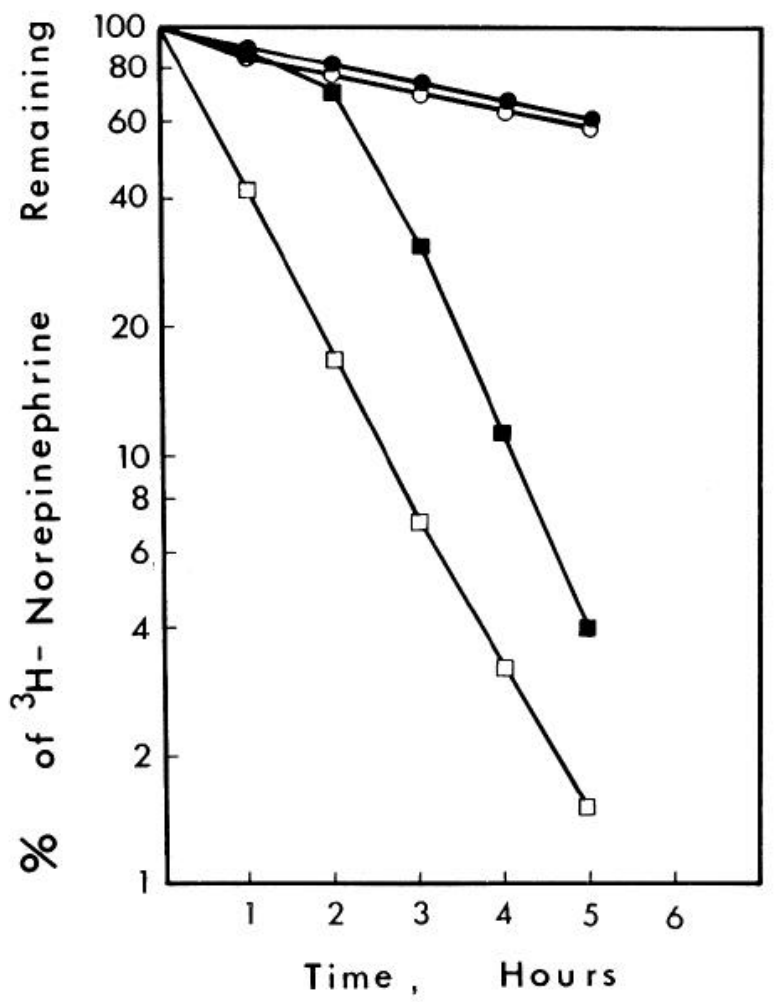

Figure 2. Threshold effect of ouabain on the release of $\left[{ }^{3} \mathrm{H}\right]$ norepinephrine - control; O, $3 \times 10^{-4} \mathrm{M}$ ouabain; $\mathbf{\square}, 10^{-3} \mathrm{M}$ ouabain; $\square, 3 \times 10^{-3} \mathrm{M}$ ouabain.

$2 \mathrm{hr}$ and then abruptly increased to the rate seen in the presence of $3 \times 10^{-3} \mathrm{M}$ ouabain. Such a delayed effect of ouabain suggests that release is a result of cumulative changes inside the cells, rather than of an immediate consequence of inhibition of the pump.

It is possible that ouabain might elicit transmitter release at lower concentrations if the cells were electrically active and, thus, had increased fluxes of either $\mathrm{Na}^{+}$or $\mathrm{Ca}^{2+}$. Accordingly, the effect of ouabain was examined in the presence of $54 \mathrm{~mm} \mathrm{~K}^{+}$or of low levels $\left(10^{-5} \mathrm{M}\right)$ of $\mathrm{A} 23187$. As in unstimulated cells, however, no consistent effect of ouabain could be demonstrated at concentrations of $10^{-3}$ $\mathrm{M}$ or lower (data not shown).

The high concentrations of ouabain required to elicit release suggest that the release may be in response to toxic conditions. Evidence that prolonged ouabain treatment is toxic comes from the observation that in some experiments it resulted in unmistakable deterioration of neurite structure (Fig. 3). The neuronal cell bodies in the cultures still looked similar to those in the controls, both by Nomarski and by phase contrast optics (not shown). When the cultures were fed complete culture medium and returned to the incubator, the cell bodies survived for more than a week, but there was little detectable recovery of normal axonal structure. Similar observations were made by Birks (1962) with electron microscopy of ouabain-treated superior cervical ganglia and neuromuscular junctions. However, with the cultured sympathetic neurons used here, the light microscopic appearance of the neuronal processes was always normal for the first several hours of ouabain treatment, and in fact structural deterioration was not seen consistently even after $6 \mathrm{hr}$ in ouabain. There appear to be plating-to-plating differences in the ability of the cells to withstand the insult.

Norepinephrine release in response to conventional stimuli. To establish a basis for comparison with ouabain, elevated extracellular $\mathrm{K}^{+}$and the $\mathrm{Ca}^{2+}$ ionophore A23187 were tested for their ability to elicit the release of $\left[{ }^{3} \mathrm{H}\right]$ norepinephrine (Fig. $4, A$ and $B$ ). Elevated extracellular $\mathrm{K}^{+}$depolarizes the cells and is thought to permit the entry of $\mathrm{Ca}^{2+}$ through voltage-sensitive channels (Blaustein et al.,
1972). $\mathrm{K}^{+}$at $54 \mathrm{~mm}$ reduced the half-time of $\left[{ }^{3} \mathrm{H}\right]$ norepinephrine release from $>360 \mathrm{~min}$ to $66 \mathrm{~min}$ in the presence of extracellular $\mathrm{Ca}^{2+}$, but had very little effect when $\mathrm{Ca}^{2+}$ was omitted from the solutions (Fig. 4A). A23187 is a $\mathrm{Ca}^{2+}$ ionophore that has been observed to induce exocytotic release in a variety of cells (Pressman, 1976). A single application of A23187 at $3 \times 10^{-5} \mathrm{M}$ was sufficient to sustain a rapid rate of norepinephrine release for several hours (Fig. $4 B$ ); the drug readily penetrates the membrane and does not appear to wash out of the cells. The ionophore caused release even in the nominal absence of extracellular $\mathrm{Ca}^{2+}$, suggesting that it may release $\mathrm{Ca}^{2+}$ from intracellular stores.

The dependence of norepinephrine release on exogenous $\mathrm{Ca}^{2+}$ was tested by omitting $\mathrm{Ca}^{2+}$ from the medium and replacing it with additional $\mathrm{Mg}^{2+}$. In intact tissues, $\mathrm{Ca}^{2+}$ may leak from considerable intracellular stores into a restricted extracellular space, making it essential to use a $\mathrm{Ca}^{2+}$ buffer to keep the extracellular concentration low, but in the dilute environment of the cultures the omission of $\mathrm{Ca}^{2+}$ alone was sufficiently harsh to cause the cells to deteriorate after a period of hours. Spontaneous release of $\left[{ }^{3} \mathrm{H}\right]$ norepinephrine was unaltered for 4 to $6 \mathrm{hr}$ (Fig. $4 A$; no $\mathrm{Ca}^{2+}$ control), but after prolonged $\mathrm{Ca}^{2+}$ deprivation, the cells released $\left[{ }^{3} \mathrm{H}\right]$ norepinephrine at an accelerated rate by an unknown mechanism. This may have been a consequence of cell death; neurons incubated without $\mathrm{Ca}^{2+}$ for $24 \mathrm{hr}$ deteriorated to the extent that they lost the ability to incorporate labeled L-leucine into protein (data not shown).

In the experimental protocol used, the cultures are in contact with the newly released $\left[{ }^{3} \mathrm{H}\right]$ norepinephrine and are able to recapture some of it by high affinity uptake. To test the effect of recapture on the apparent rate of release, the experiments were repeated in the presence of the uptake inhibitor, desipramine (Iversen, 1975). Figure $5, A$ and $B$, shows that $10^{-5} \mathrm{M}$ desipramine potentiates the apparent rate of release of $\left[{ }^{3} \mathrm{H}\right]$ norepinephrine elicited both by high $\mathrm{K}^{+}$and by $A 23187$. Desipramine had no detectable effect on the release of radioactivity from unstimulated cultures (not shown); such release has previously been shown to consist primarily of deaminated metabolites of norepinephrine, which are thought to diffuse passively from the cells (Patterson et al., 1976).

The desipramine-sensitive norepinephrine uptake from the extracellular medium is known to be due to an $\mathrm{Na}^{+}$-dependent carrier, and it should be possible to block it by reducing the concentration of extracellular $\mathrm{Na}^{+}$. The effect of reducing extracellular $\mathrm{Na}^{+}$to 14 $\mathrm{mm}$, using choline as a substitute to maintain osmolarity and ionic strength, was tested accordingly. Figure $6, A$ and $B$, shows that medium containing $14 \mathrm{mM} \mathrm{Na}^{+}$had little or no effect on the release
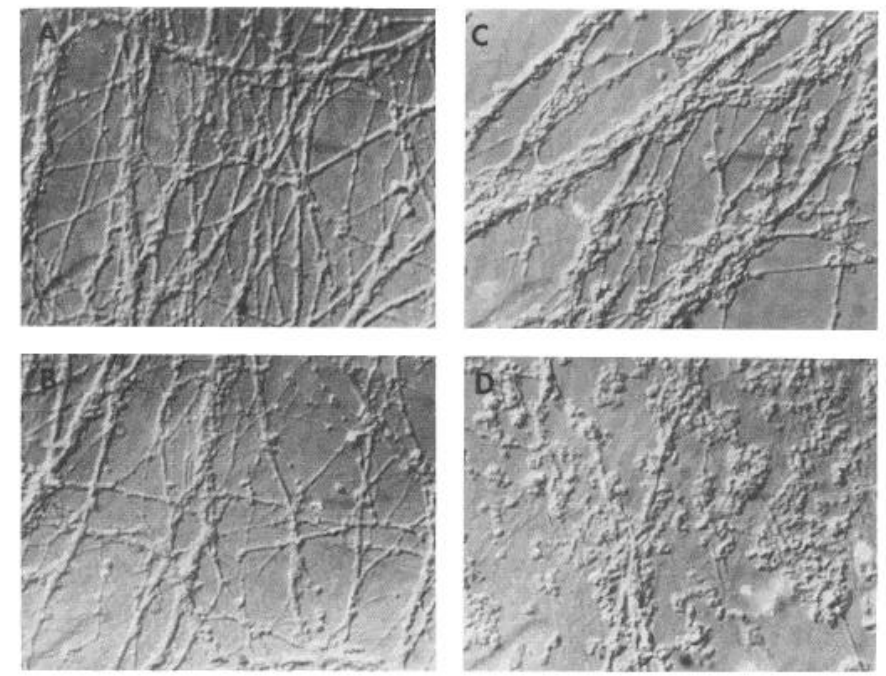

Figure 3. Light microscopic appearance of neuronal processes after extended treatment with ouabain. Neuronal processes were photographed at $\times 600$ with Nomarski optics. $A$, Control; $B$, after $6 \mathrm{hr}$ in $10^{-5} \mathrm{M}$ veratridine; $C$, after $6 \mathrm{hr}$ in $10^{-3} \mathrm{M}$ ouabain; $D$, after $6 \mathrm{hr}$ in $3 \times 10^{-3} \mathrm{M}$ ouabain. 

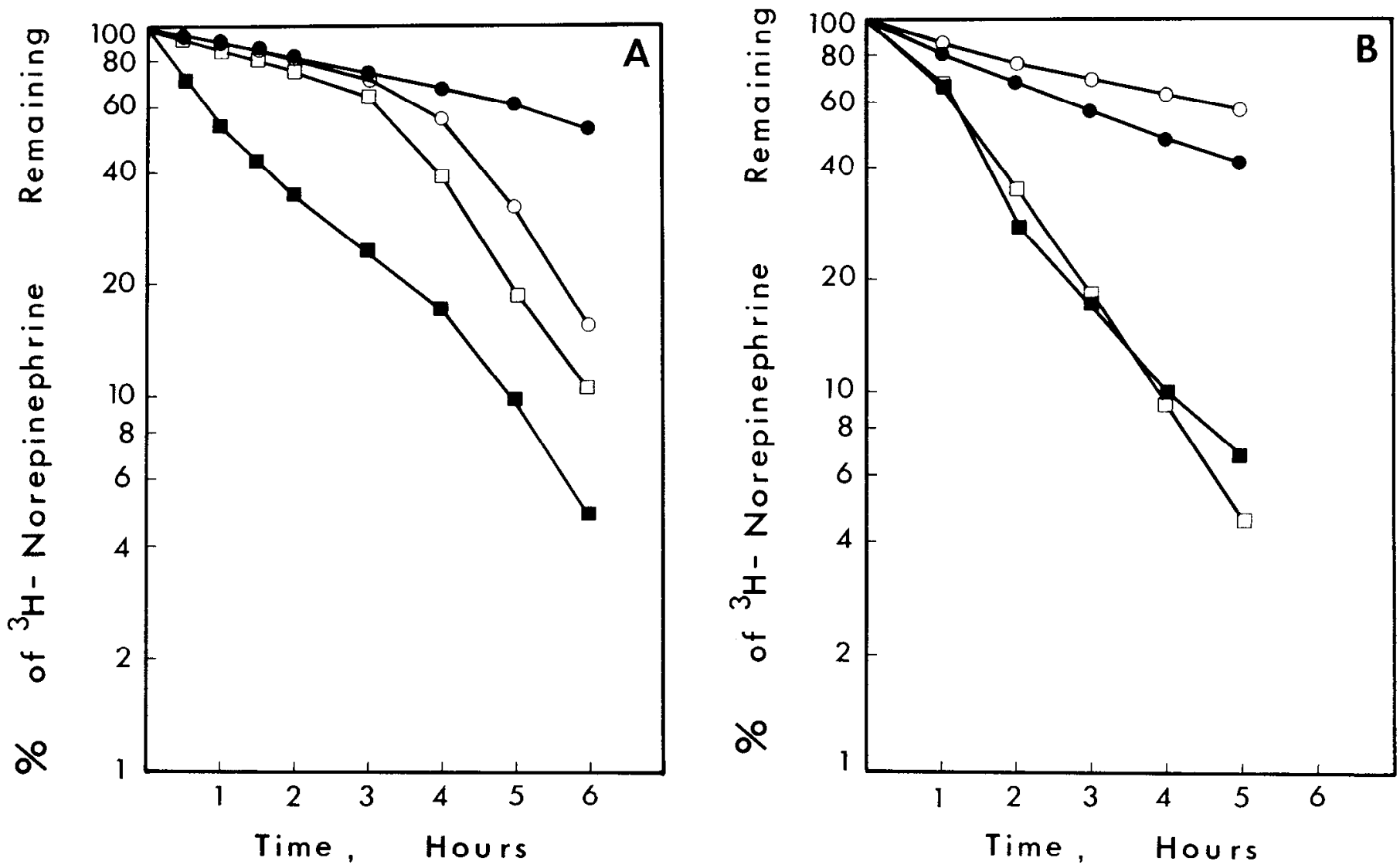

Figure 4. A, Norepinephrine release elicited by high $\mathrm{K}^{+}$in the presence and absence of extracellular $\mathrm{Ca}^{2+}$. Normally the salts solution contains $140 \mathrm{~mm}$ $\mathrm{Na}^{+}$and $5.4 \mathrm{mM} \mathrm{K}^{+}$. When $54 \mathrm{mM} \mathrm{K}^{+}$was used, $\mathrm{Na}^{+}$was reduced to $91.4 \mathrm{~mm}$ to maintain isotonicity. $\bullet$, control; $O$, control minus Ca ${ }^{2+} ; \mathbf{\square}, 54$ mM $\mathrm{K}^{+} ; \square$, $54 \mathrm{mM} \mathrm{K}{ }^{+}$minus $\mathrm{Ca}^{2+}$. The ordinate shows the calculated percentage of the total $\left[{ }^{3} \mathrm{H}\right]$ norepinephrine remaining in the cells at each time point. $B$, Norepinephrine release elicited by the $\mathrm{Ca}^{2+}$ ionophore $\mathrm{A} 23187$ in the presence and absence of extracellular $\mathrm{Ca}^{2+}, \mathrm{O}_{1}$ control; $\mathrm{O}$, control minus $\mathrm{Ca}^{2+} ; \square$, A23187 $\left(3 \times 10^{-5} \mathrm{M}\right) ; \mathbf{\square}, \mathrm{A} 23187$ minus $\mathrm{Ca}^{2+}$.

of radioactivity from control cultures, but it potentiated the release from cells stimulated with $54 \mathrm{mM} \mathrm{K}^{+}$or A23187 much as did desipramine.

$\mathrm{Ca}^{2+}$ and $\mathrm{Na}^{+}$dependence of the effect of ouabain. Ouabain and strophanthidin elicited rapid release of $\left[{ }^{3} \mathrm{H}\right]$ norepinephrine at concentrations of $3 \times 10^{-3} \mathrm{M}$, and this release was not dependent upon the presence of $\mathrm{Ca}^{2+}$ in the extracellular medium (Fig. 7). As a control for the leakage of $\mathrm{Ca}^{2+}$ from intracellular pools into the extracellular medium, ouabain was also tested in a $\mathrm{Ca}^{2+}$-EGTA (ethyleneglycol bis-( $\beta$-aminoethyl ether)- $N, N^{\prime}$-tetra-acetic acid) buffer with a final concentration of $\mathrm{Ca}^{2+}$ of $10^{-7} \mathrm{M}$ (Graf and Penniston, 1981), with the same result.

If the effect of inhibition of the Na,K-ATPase on transmitter release were a consequence of a net rise in the concentration of intracellular $\mathrm{Na}^{+}$, any experimental condition that reduces $\mathrm{Na}^{+}$influx might be predicted to block the effect of ouabain. Experiments were thus performed in a medium containing only $14 \mathrm{mM} \mathrm{Na}^{+}$with choline as a substitute, instead of $140 \mathrm{mM} \mathrm{Na}{ }^{+}$. Ouabain did not elicit the release of $\left[{ }^{3} \mathrm{H}\right]$ norepinephrine in $14 \mathrm{mM} \mathrm{Na}^{+}$(Fig. 8). This contrasts with the potentiating effect of similar ionic conditions on release elicited by high $\mathrm{K}^{+}$or $\mathrm{A} 23187$ (Fig. $6, A$ and $B$ ).

It is critical to know whether ouabain still inhibits the Na,K-ATPase in these altered ionic conditions; therefore, inhibition was measured in vitro in a reaction mixture containing $14 \mathrm{mM} \mathrm{NaCl}$ and $126 \mathrm{~mm}$ choline chloride and compared to the values obtained in the presence of $140 \mathrm{~mm} \mathrm{NaCl}$. As in the experiment shown in Figure 1, $\mathrm{CaCl}_{2}$ was omitted from the standard minimal salts solution, and the reaction mixture contained $3 \mathrm{mM} \mathrm{ATP}$ and $3 \mathrm{mM} \mathrm{MgCl}_{2}$. The result was that equilibrium half-maximal inhibition occusred at $3.1 \times 10^{-5}$ $\mathrm{M}$ ouabain in $140 \mathrm{~mm} \mathrm{NaCl}$ and at $3.3 \times 10^{-5} \mathrm{M}$ in $14 \mathrm{~mm} \mathrm{NaCl}, 126$
$\mathrm{mM}$ choline chloride. Since no transmitter release occurs with as much as $3 \times 10^{-3} \mathrm{M}$ ouabain in these ionic conditions, it would appear that inhibition of the Na,K-ATPase alone is not sufficient to cause the release.

Lowering extracellular $\mathrm{Na}^{+}$would reduce the electrochemical driving force for $\mathrm{Na}^{+}$entry and could have at least two consequences: it could reduce passive $\mathrm{Na}^{+}$influx or it could reduce $\mathrm{Na}^{+}: \mathrm{Ca}^{2+}$ exchange. Tetrodotoxin at $10^{-5} \mathrm{M}$ was found to delay the onset of ouabain-evoked [ ${ }^{3} \mathrm{H}$ ]norepinephrine release by 2 to $3 \mathrm{hr}$ (Fig. 9). Although the voltage-sensitive $\mathrm{Na}^{+}$gate is only one of several probable routes by which $\mathrm{Na}^{+}$could enter the cell, it appears to make a significant contribution in the present experiments, supporting the hypothesis that net $\mathrm{Na}^{+}$influx is the critical factor.

Norepinephrine release via a carrier. The results of Figures 8 and 9 are most simply interpreted as consistent with the hypothesis that ouabain-elicited norepinephrine release is the consequence of a rise in the concentration of intracellular $\mathrm{Na}^{+}$. A simple model to explain release of $\left[{ }^{3} \mathrm{H}\right]$ norepinephrine that is independent of extracellular $\mathrm{Ca}^{2+}$ and dependent on a rise in intracellular $\mathrm{Na}^{+}$is that it could occur by efflux on the plasma membrane carrier instead of by exocytosis. To test this, desipramine was used to block the norepinephrine carrier while the Na,K-ATPase was inhibited with ouabain. Figure 10 shows that desipramine at $10^{-5} \mathrm{M}$ completely blocked ouabain-elicited $\left[{ }^{3} \mathrm{H}\right]$ norepinephrine release. In other experiments it was determined that $10^{-6} \mathrm{M}$ desipramine would block ouabainelicited $\left[{ }^{3} \mathrm{H}\right]$ norepinephrine release by 30 to $40 \%$, whereas $10^{-7} \mathrm{M}$ desipramine was without effect (data not shown).

Norepinephrine release in veratridine. Veratridine depolarizes neurons by opening the voltage-sensitive $\mathrm{Na}^{+}$channel, and it has been used by other investigators to elicit transmitter release (reviewed in 

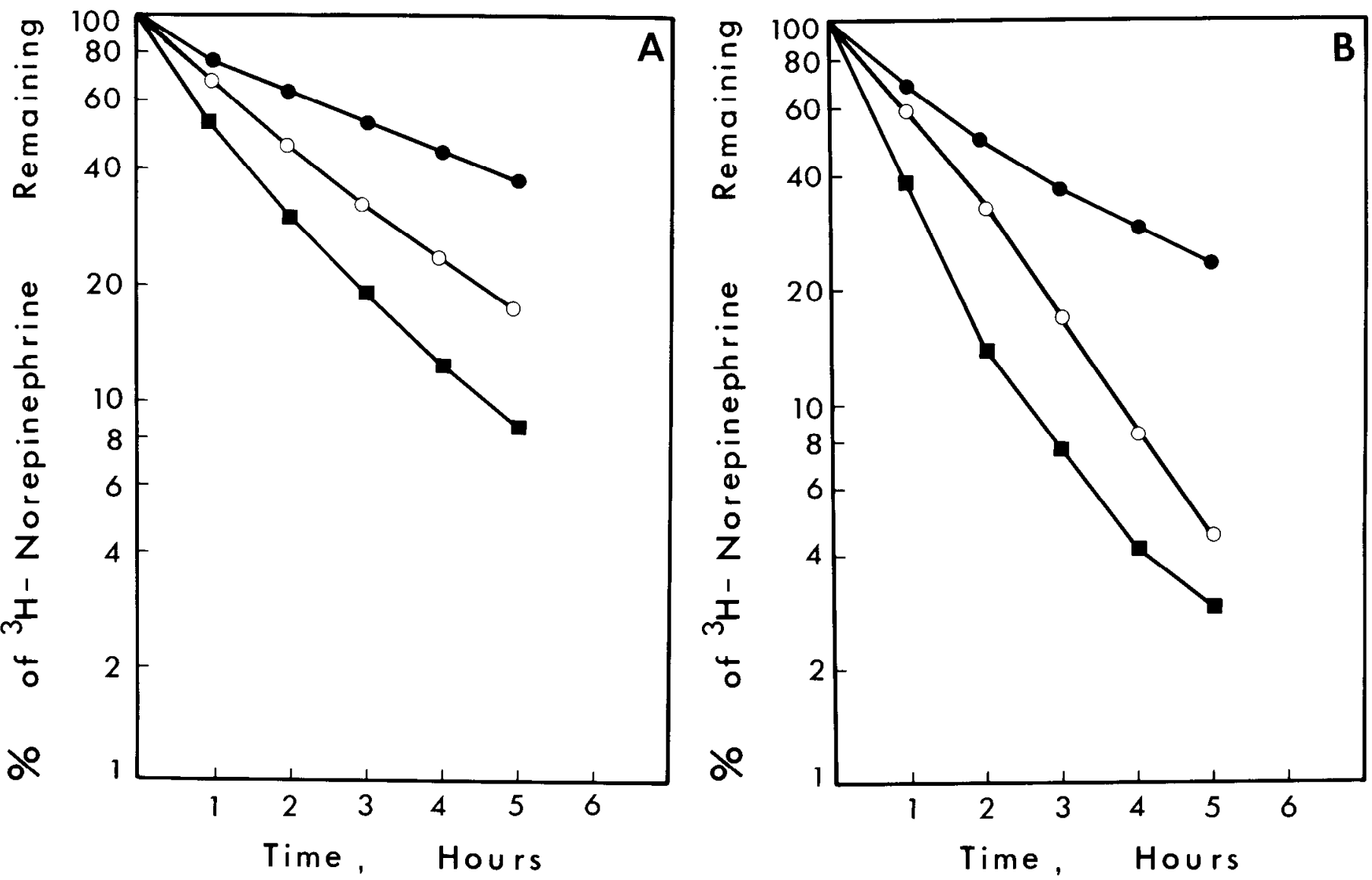

Figure 5. $\wedge$, Norcpincphrine relcase clicited by high $\mathrm{K}^{+}$in the presence and absence of the norepinephrine uptake inhibitor desipramine. 9 , control; $\mathrm{O}$, $54 \mathrm{mM} \mathrm{K}^{+} ; 54 \mathrm{mM} \mathrm{K}^{+}$plus $10^{-5} \mathrm{M}$ desipramine. $B$, Norepinephrine release elicited by A23187 in the presence and absence of desipramine. control; O. A23187 $\left(3 \times 10^{-5} \mathrm{M}\right) ; \mathbf{\square}$, A23187 plus $10^{-5} \mathrm{M}$ desipramine.

Minchin, 1980). It caused release of $\left[{ }^{3} \mathrm{H}\right]$ norepinephrine from the cultured sympathetic neurons both in the presence and in the nominal absence of $\mathrm{Ca}^{2+}(\mathrm{Fig} .11 \mathrm{~A})$. The effect of veratridine was blocked by $10^{-5} \mathrm{M}$ tetrodotoxin, as expected from its specificity for the $\mathrm{Na}^{+}$channel, and, in fact, tetrodotoxin could restore the resting rate of $\left[{ }^{3} \mathrm{H}\right]$ norepinephrine release after 2 to $3 \mathrm{hr}$ of veratridinestimulated release (data not shown). In contrast to the release elicited by ouabain, however, the release elicited by veratridine was inhibited only approximately $50 \%$ by the carrier blocker desipramine (Fig. $11 B)$.

Norepinephrine release in the absence of $\mathrm{Na}^{+}$. In Figure 6 it was shown that replacing all but $14 \mathrm{mM} \mathrm{Na}^{+}$in the extracellular medium with choline had no effect on the resting rate of $\left.{ }^{3} \mathrm{H}\right]$ norepinephrine release. Complete removal of extracellular $\mathrm{Na}^{+}$should have the effect of reversing the dircction of the $\mathrm{Na}^{+}$gradient across the membrane, and this would be predicted to drive the efflux of $\left[{ }^{3} \mathrm{H}\right]$ norepinephrine on the plasma membrane carrier even more effectively than the elevated intracellular $\mathrm{Na}^{+}$concentrations produced by ouabain. As predicted, replacing all of the $\mathrm{Na}^{+}$with choline elicited transmitter release (Fig. 12). Substitution of $\mathrm{Li}^{+}$or $\mathrm{N}$-methylglucamine for $\mathrm{Na}^{+}$had a similar result, except that release rate tended to be higher. This effect of $\mathrm{Na}^{+}$depletion did not depend on the presence of $\mathrm{Ca}^{2+}$ in the extracellular medium, and it was neither enhanced nor inhibited consistently by treating the cells with ouabain, tetrodotoxin, or desipramine (not shown). The problem with complete substitution of the $\mathrm{Na}^{+}$in the extracellular medium was that the resulting transmitter release rates were usually highly variable, even when triplicate cultures from the same platings were compared. The complete removal of $\mathrm{Na}^{+}$appears to have complex consequences that we do not understand; thus, no confidence can be placed on an analysis of its mechanism.

\section{Discussion}

The experiments reported here suggest that inhibition of the $\mathrm{Na}, \mathrm{K}$ ATPase with ouabain results in $\left[{ }^{3} \mathrm{H}\right]$ norepinephrine release from intact sympathetic neurons by a mechanism quite different from conventional release by exocytosis. The effect of ouabain was not abolished in the nominal absence of $\mathrm{Ca}^{2+}$. It required conditions permissive for passive $\mathrm{Na}^{+}$influx, and it was inhibited by a drug, desipramine, which blocks the $\mathrm{Na}^{+}$-dependent norepinephrine carrier (Iversen, 1975; Raiteri and Levi, 1978). The simplest explanation is that ouabain permits intracellular $\mathrm{Na}^{+}$levels to rise to the point that the carrier can run backwards: not necessarily at a rate comparable to its normal influx mode, but at a rate sufficient to allow a net efflux of the transmitter from the cell. Both high $\mathrm{K}^{+}$and ouabain treatments are capable of producing nearly complete depletion of intracellular norepinephrine, which implies an equilibrium between the vesicular and cytoplasmic pools.

The mechanism of ouabain-elicited release. The most widely accepted model for transmitter release is that it occurs by exocytosis, dependent on an influx of extracellular $\mathrm{Ca}^{2+}$. Three laboratories have found ouabain-elicited catecholamine release from the adrenal medulla that is dependent on the presence of millimolar levels of exogenous $\mathrm{Ca}^{2+}$ (Banks, 1967; Garcia et al., 1980; Wakade, 1981), and a similar observation has been made for norepinephrine release from sympathetic neurons innervating the vas deferens (Nakazato et al., 1978). Other laboratories have found ouabain-evoked release that is only partially dependent on extracellular $\mathrm{Ca}^{2+}$ : in vascular smooth muscle (Lorenz, Powis, Vanhoutte, and Shephard, 1980; Palaty, 1981) and in skeletal muscle (Elmqvist and Feldman, 1965; Birks and Cohen, 1968; Baker and Crawford, 1975; Branisteanu et al., 1979; Vizi and Vyskocil, 1979). A lack of dependence on extracellular $\mathrm{Ca}^{2+}$ is not in itself sufficient evidence to argue that 

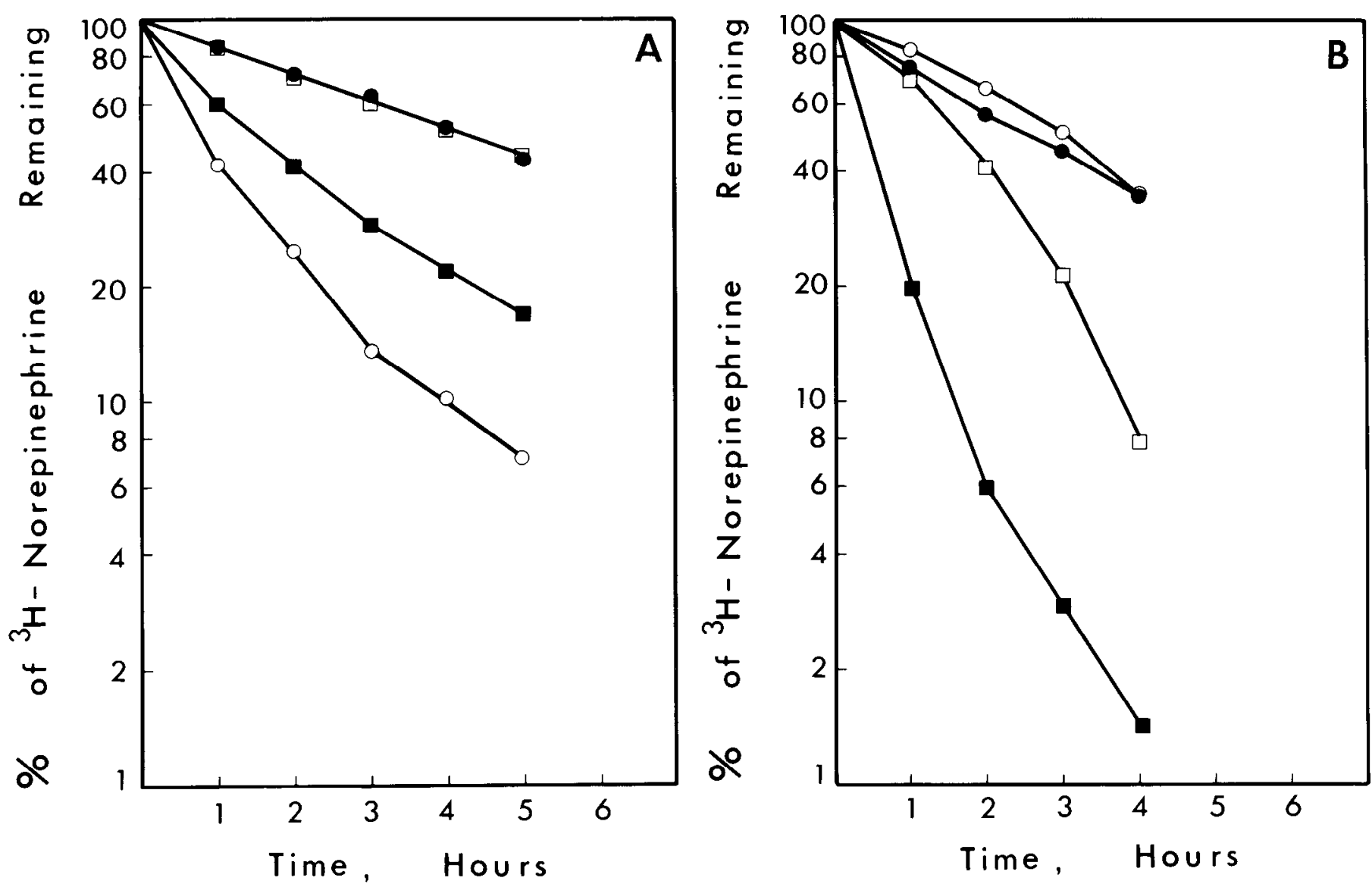

Higure 6. A, Norepinephrine release elicited by high $\mathrm{K}^{+}$in the presence and absence of reduced extracellular $\mathrm{Na}^{+}$. $\bullet$, control; $\square$, control with $14 \mathrm{mM} \mathrm{Na}^{+}$ and $126 \mathrm{~mm}$ choline chloride;, $54 \mathrm{mM} \mathrm{K}^{+}$and $91.4 \mathrm{mM} \mathrm{Na}^{+} ; 0,54 \mathrm{mM} \mathrm{K}^{+}, 14 \mathrm{mM} \mathrm{Na}^{+}$, and $77.4 \mathrm{~mm}$ choline chloride. $B$, Norepinephrine release elicited by $A 23187$ in the presence and absence of reduced extracellular $\mathrm{Na}^{+}$., control; $O$, control with $14 \mathrm{mM} \mathrm{Na}^{+}$and $126 \mathrm{~mm}$ choline chloride; $\square, A 23187\left(10^{-5}\right.$ M); $\mathbf{\square}$, A23187 in $14 \mathrm{~mm} \mathrm{Na}^{+}$and $126 \mathrm{~mm}$ choline chloride.

trasmitter release is nonvesicular, since vesicular release may result from the mobilization of intracellular $\mathrm{Ca}^{2+}$ stores or a reduction in $\mathrm{Ca}^{2+}$ efflux. Catecholamine release from the adrenal medulla has been shown to be accompanied by the release of the chromaffin granule protein dopamine $\beta$-hydroxylase both when release was $\mathrm{Ca}^{2+}$ dependent (Garcia et al., 1980) and when it was $\mathrm{Ca}^{2+}$ independent (Lastowecka and Trifaro, 1974; Pocock, 1983a). In these cases, it is very likely that release was occurring by exocytosis. Unfortunately, we have been unable to detect release of dopamine $\beta$-hydroxylase from rat sympathetic neurons under any experimental condition; thus, we have no positive evidence for the absence of vesicular release in the present experiments (data not shown).

The results presented in this report do not rule out an effect of ouabain on $\mathrm{Ca}^{2+}$ influx, $\mathrm{Na}^{+}: \mathrm{Ca}^{2+}$ exchange, or the mobilization of $\mathrm{Ca}^{2+}$ from intracellular stores, but they can be most simply explained by a minimal model which requires only that the concentration of intracellular $\mathrm{Na}^{+}$rise and that transmitter leak from the cell as a result of the reversibility of an $\mathrm{Na}^{+}$-dependent membrane carrier. No dependence on extracellular $\mathrm{Ca}^{2+}$ could be demonstrated for the effect of ouabain, even when $\mathrm{Ca}^{2+}$ was buffered at $10^{-7} \mathrm{M}$, which eliminates the need to invoke depolarization-induced activation of $\mathrm{Ca}^{2+}$ channels or an increased $\mathrm{Ca}^{2+}$ influx through $\mathrm{Na}^{+}: \mathrm{Ca}^{2+}$ exchange. Another plausible model would be that $\mathrm{Ca}^{2+}$ efflux through $\mathrm{Na}^{+}: \mathrm{Ca}^{2+}$ exchange is decreased because of an increase in intracellular $\mathrm{Na}^{+}$, resulting in a higher intracellular level of $\mathrm{Ca}^{2+}$. This does not easily explain the effect of ouabain in causing release, however, because of the observed effect of reducing extracellular $\mathrm{Na}^{+}$. The presence of only $14 \mathrm{mM} \mathrm{Na}^{+}$in the extracellular medium would be expected to have a qualitatively similar effect on $\mathrm{Ca}^{2+}$ efflux, and yet it blocks the effect of ouabain, rather than enhancing it. It is simpler to suppose that reducing the concentration of extracellular $\mathrm{Na}^{+}$limits the passive rise in intracellular $\mathrm{Na}^{+}$which follows the inhibition of the $\mathrm{Na}^{+}$pump. The effect of tetrodotoxin in delaying ouabain-elicited release strengthens this argument, since tetrodotoxin should act only to reduce $\mathrm{Na}^{+}$influx. An increase in the concentration of intracellular $\mathrm{Na}^{+}$may ultimately result in the release of $\mathrm{Ca}^{2+}$ from mitochondria (Carafoli, 1982), but there is no known reason to postulate an effect of $\mathrm{Ca}^{2+}$ on the desipramine-sensitive catecholamine carrier.

The hypothesis that transmitters can sometimes be released from neurons by the reversal of plasma membrane carriers is gaining experimental support. Specific uptake blockers have been shown to prevent release of norepinephrine or dopamine (Blaszkowski and Bogdanski, 1972; Paton, 1973; Raiteri et al., 1977, 1979; Lorenz et al., 1980; Liang and Rutledge, 1982). Amphetamine-induced release of norepinephrine is also apparently carrier mediated (Rutledge, 1978). Amino acid transmitters may be released by an analogous mechanism (Levi and Raiteri, 1978; Schwartz, 1982; Yazulla and Kleinschmidt, 1983). Schwartz (1982) proposed that carrier-mediated GABA release was activated by depolarization, which is reasonable if there is a net movement of charge on the carrier. In other cases, high intracellular $\mathrm{Na}^{+}$or reversal of the $\mathrm{Na}^{+}$gradient was thought to permit the reversal of membrane carriers

In slices and synaptosomes from brain, ouabain-evoked release of acetylcholine (Vizi, 1972; Meyer and Cooper, 1981; Vyas and Marchbanks, 1981) and serotonin (Collard and Williams, 1981) is seen that is independent of extracellular $\mathrm{Ca}^{2+}$. It has been proposed by Vizi (1972) that inhibition of the Na,K-ATPase is itself sufficient, independent of fluxes of either $\mathrm{Na}^{+}$or $\mathrm{Ca}^{2+}$, to cause transmitter release by such means as destabilizing the membrane or changing 


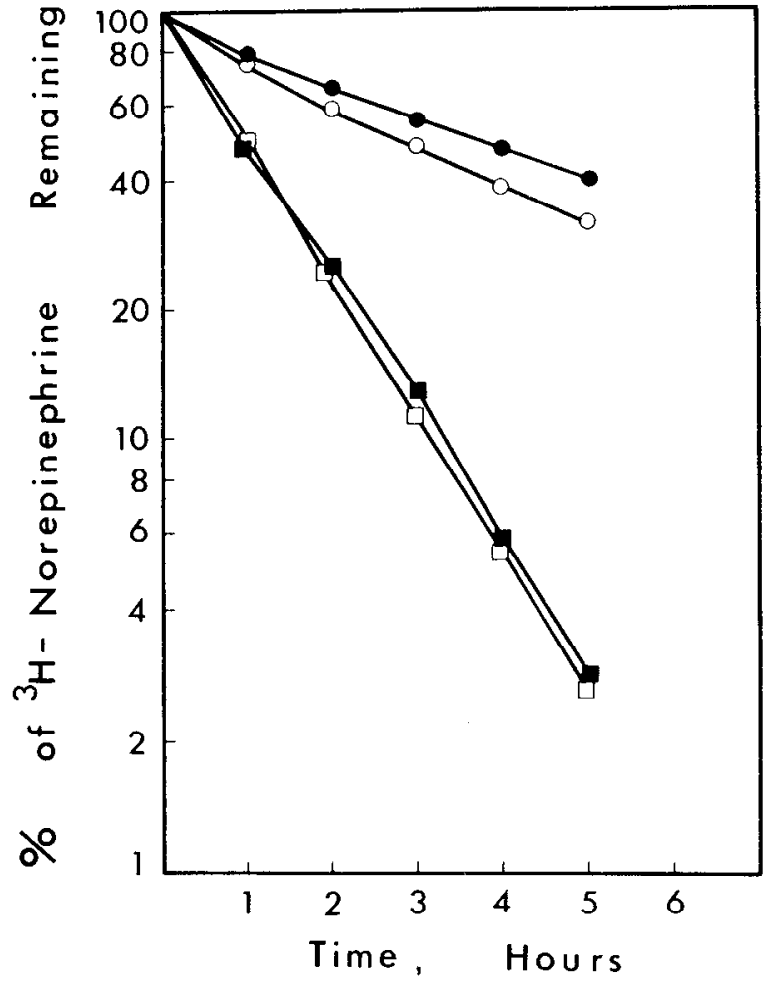

Figure 7. Norepinephrine release elicited by ouabain in the presence or absence of extracellular $\mathrm{Ca}^{2+}$. $\left(3 \times 10^{-3} \mathrm{M}\right) ; \square$, ouabain minus $\mathrm{Ca}^{2+}$.

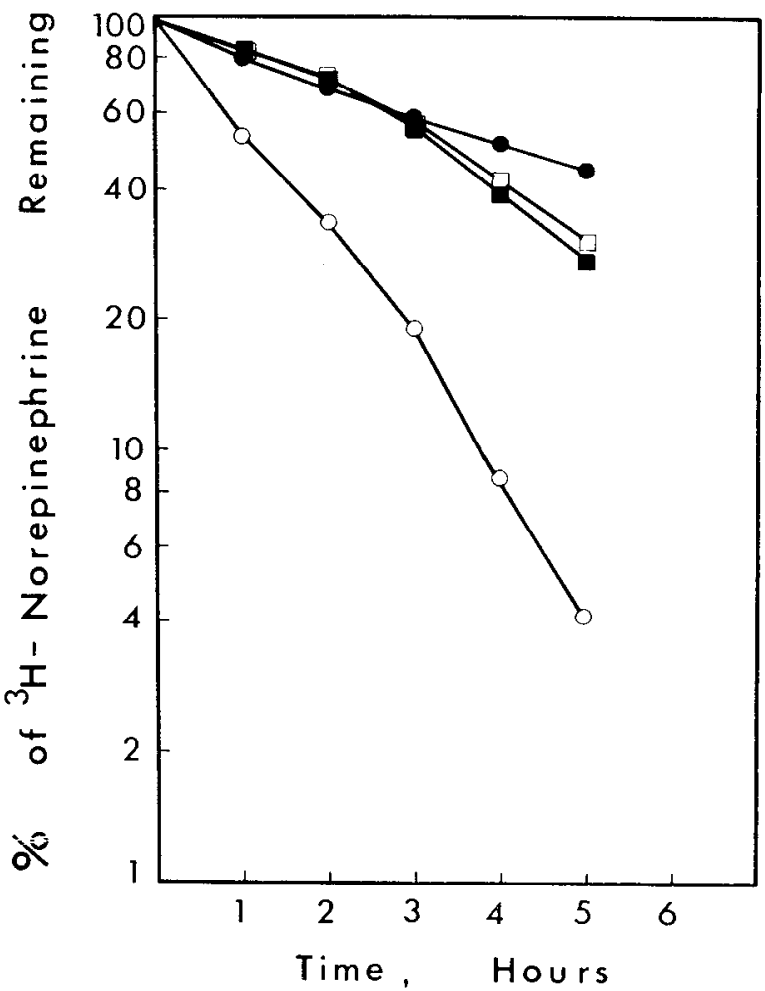

Figure 8 . Norepinephrine release elicited by ouabain in the presence or absence of reduced extracellular $\mathrm{Na}^{+}$. control: $\square$, control with $14 \mathrm{mM} \mathrm{Na}^{+}$ and $126 \mathrm{~mm}$ choline chloride; $\mathrm{O}$, ouabain $\left(3 \times 10^{-3} \mathrm{M}\right)$; $\mathbf{D}$, ouabain in $14 \mathrm{~mm}$ $\mathrm{Na}^{+}$and $126 \mathrm{~mm}$ choline chloride.

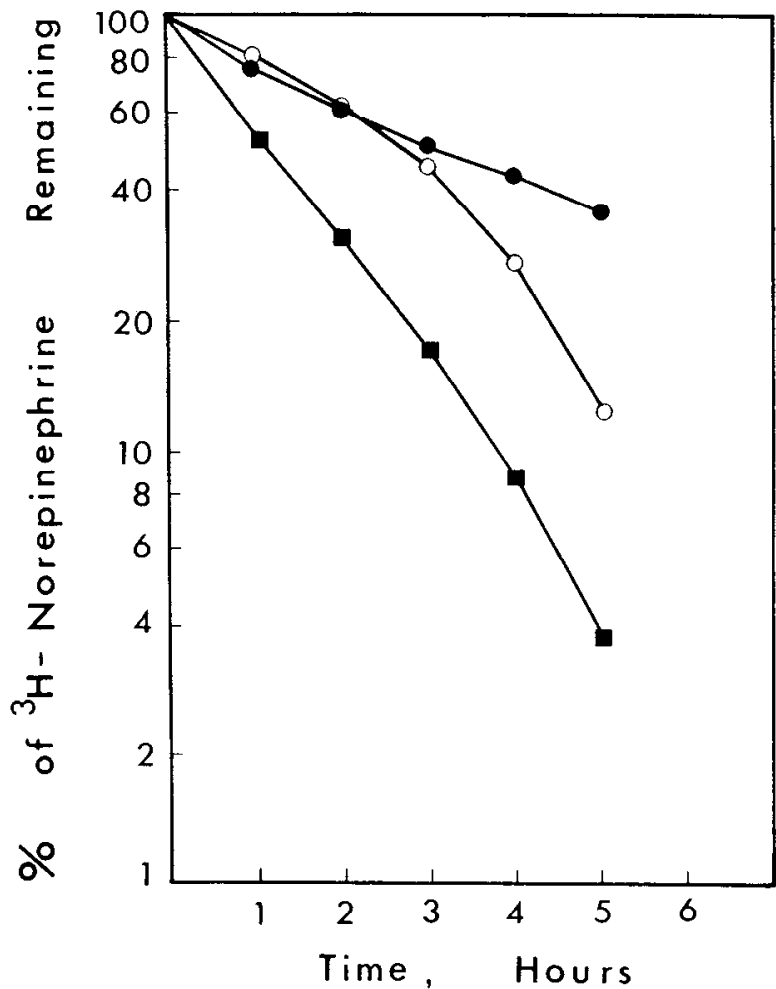

Figure 9. Norepinephrine release elicited by ouabain in the presence or absence of the voltage-sensitive $\mathrm{Na}^{+}$gate blocker, tetrodotoxin. D, ouabain $\left(3 \times 10^{-3} \mathrm{M}\right)$ : $\mathrm{O}$, ouabain plus tetrodotoxin $\left(10^{-5} \mathrm{M}\right)$.

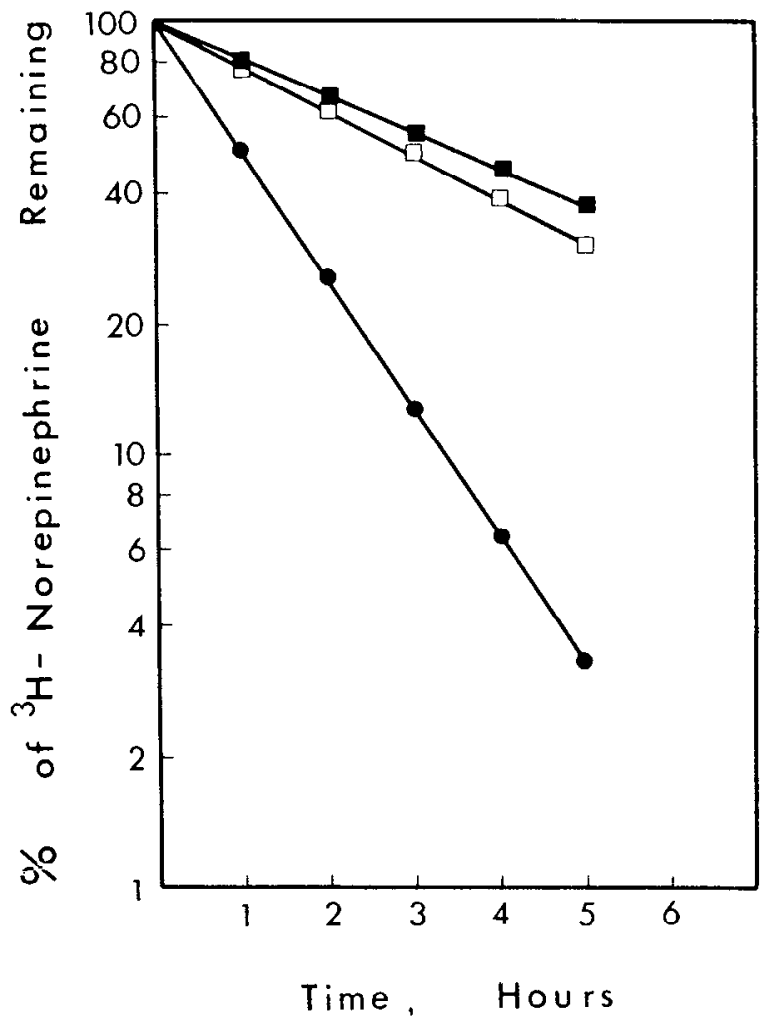

Figure 10. Norepinephrine release elicited by ouabain in the presence or absence of the norepinephrine carrier blocker, desipramine. $\boldsymbol{\square}_{\text {, control; }}$ ouabain $\left(3 \times 10^{-3} \mathrm{M}\right) ; \square$, ouabain plus desipramine $\left(10^{-5} \mathrm{M}\right)$ 

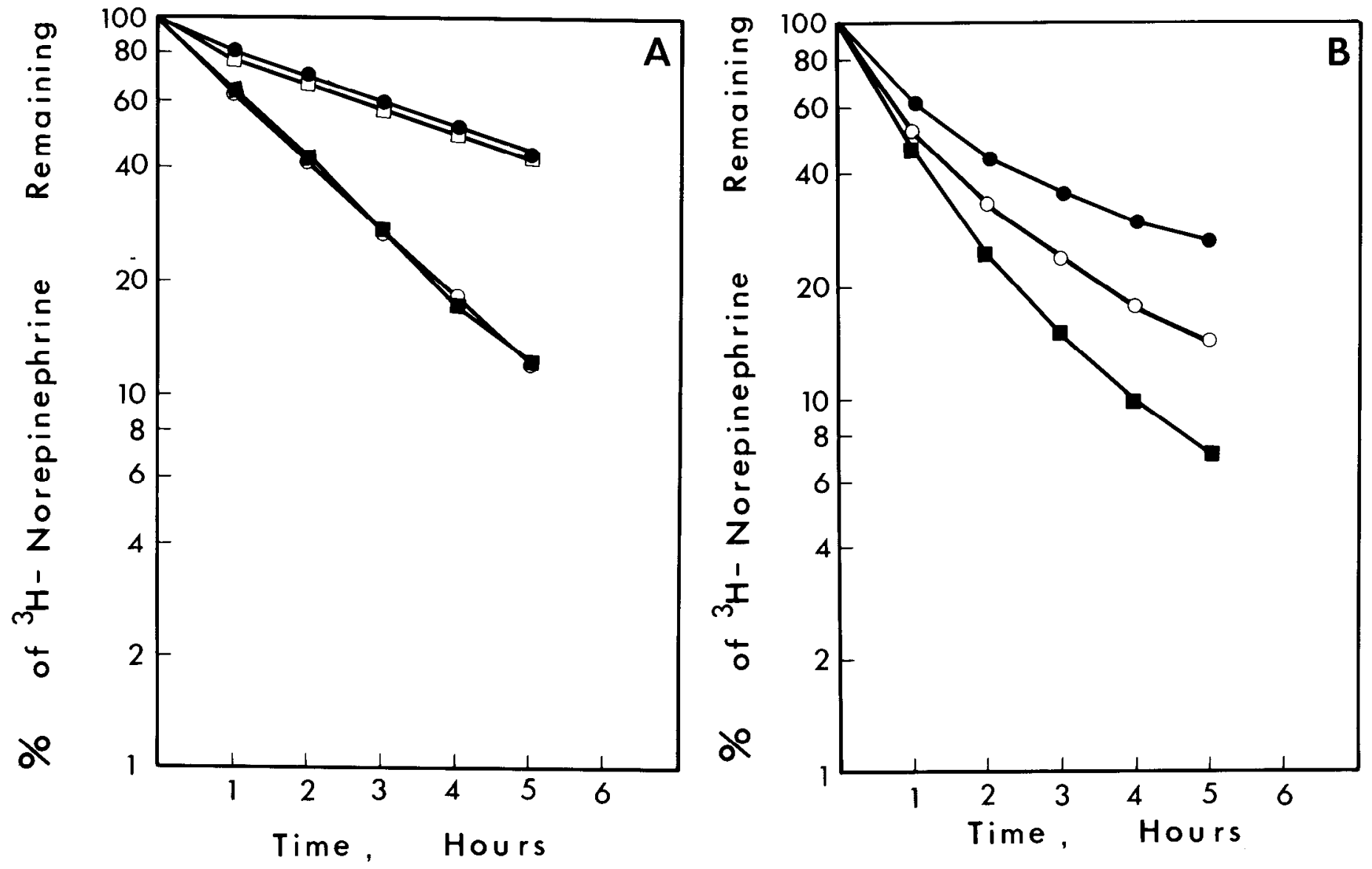

Figure 11. A, Norepinephrine release elicited by the voltage-sensitive $\mathrm{Na}^{+}$gate toxin, veratridine, in the presence or absence of extracellular $\mathrm{Ca}^{2+}$. control; $\square$, control minus $\mathrm{Ca}^{2+} ; O$, veratridine $\left(3 \times 10^{-5} \mathrm{M}\right) ; \mathbf{\square}$, veratridine minus $\mathrm{Ca}^{2+}$. $B$, Norepinephrine release elicited by veratridine in the presence or absence of desipramine. control; $\mathbf{\square}$, veratridine $\left(10^{-5} \mathrm{M}\right) ; \mathrm{O}$, veratridine plus desipramine $\left(10^{-5} \mathrm{M}\right)$.

the intracellular $\mathrm{pH}$. This model is clearly untenable here in view of the fact that the $\mathrm{Na}, \mathrm{K}$-ATPase can be inhibited by ouabain in the presence of reduced extracellular $\mathrm{Na}^{+}$, yet without any consequent release of transmitter. A dependence upon extracellular $\mathrm{Na}^{+}$(and by inference on $\mathrm{Na}^{+}$influx) has been demonstrated for the effect of ouabain on transmitter release in several laboratories (Birks, 1963; Birks and Cohen, 1968; Nakazato et al., 1978; Garcia et al., 1980; Pocock, 1983a). A reduction in extracellular $\mathrm{Na}^{+}$has also been observed to protect the neuron against the pathological changes in ultrastructure that are caused by prolonged poisoning with ouabain (Birks, 1962).

Some of the other apparent contradictions in the literature can be understood if one assumes that there are tissue- or cell-specific differences in the balance between exocytotic and carrier-mediated mechanisms. It is notable, for example, that no carrier-mediated release of catecholamines has been reported for the adrenal medulla, although that organ has been reported to have a high affinity uptake system for catecholamines analogous to the one in neurons (Kenigsberg and Trifaro, 1980; Role and Perlman, 1983). Even $\mathrm{Na}^{+}$ depletion is thought to cause exocytotic release in the adrenal medulla (Lastowecka and Trifaro, 1974; Nishimura et al., 1981). Veratridine, which opens the voltage-sensitive $\mathrm{Na}^{+}$gate, causes release from cultured sympathetic neurons that is independent of extracellular $\mathrm{Ca}^{2+}$ and that is at least partially inhibitable by desipramine. This contrasts with observations on rat brain synaptosomes, where the effect of veratridine was $\mathrm{Ca}^{2+}$ dependent and unaffected by desipramine (Mulder et al., 1975), and where it causes an increase in $\mathrm{Ca}^{2+}$ accumulation (Blaustein, 1975). Since veratridine depolarizes the cell, allowing $\mathrm{Ca}^{2+}$ to enter through voltage-sensitive channels as well as permitting diffusion-limited $\mathrm{Na}^{+}$entry through the $\mathrm{Na}^{+}$ gate, it is plausible that either $\mathrm{Ca}^{2+}$-dependent or $\mathrm{Na}^{+}$-dependent release mechanisms might predominate in different kinds of cells.

The lack of $\mathrm{Na}^{+}$in the extracellular medium would be predicted to cause release by reversing the direction of the $\mathrm{Na}^{+}$gradient, and yet desipramine had no consistent effect on norepinephrine release from sympathetic neurons in this condition. This may be due to a failure of the cells to maintain their integrity after prolonged $\mathrm{Na}^{+}$ depletion. In synaptosomes, however, desipramine and nomifensine have been found to cause partial inhibition of norepinephrine and dopamine release into medium lacking $\mathrm{Na}^{+}$(Paton, 1973; Raiteri et al., 1977, 1979). Desipramine, like norepinephrine itself, may require extracellular $\mathrm{Na}^{+}$for binding to the carrier (Lee and Snyder, 1981), with the consequence that it is ineffective in inhibiting outward transport into medium lacking $\mathrm{Na}^{+}$at the concentrations used. Alternatively, desipramine may need to enter the cell by the $\mathrm{Na}^{+}$ dependent carrier before it can inhibit norepinephrine efflux.

Ouabain concentration and its physiological effects. The affinity of the Na,K-ATPase for ouabain can vary markedly depending on the species and on the concentration of $\mathrm{K}^{+}$(Schwartz et al., 19/b) and, in certain species, on which of two different forms of the $\mathrm{Na}, \mathrm{K}$ ATPase catalytic subunit is present. The two forms of the $\mathrm{Na}, \mathrm{K}$ ATPase have been separated, and are named $\alpha$, the kidney form, and $\alpha(+)$, the axolemma form, after their richest tissue sources (Sweadner, 1979). In the rat, the kidney form, $\alpha$, has an affinity for ouabain of $3 \times 10^{-5} \mathrm{M}$ as reported here, whereas the axolemma form, $\alpha(+)$, has an affinity of $10^{-7} \mathrm{M}$ (unpublished results).

It has been postulated that some of the physiological effects of ouabain on target tissues of the autonomic nervous system are a consequence of the release of neurotransmitter rather than of a direct effect of the drug on the target (reviewed by Gillis and Quest, 


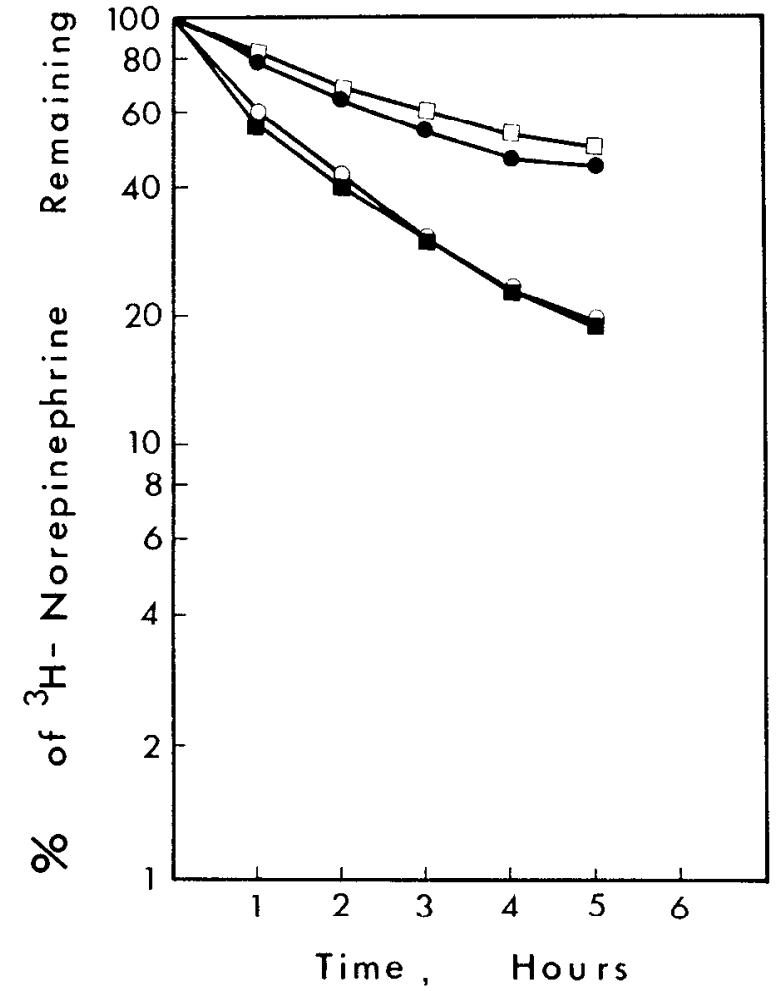

Figure 12. Norepinephrine release elicited by the lack of extracellular $\mathrm{Na}^{+}$ in the presence or absence of extracellular $\mathrm{Ca}^{2+}$. control; $\square$, control minus $\mathrm{Ca}^{2+} ; \mathbf{O}, 0 \mathrm{Na}^{+}, 140 \mathrm{~mm}$ choline chloride; $\mathrm{O}, 0 \mathrm{Na}^{+}, 140 \mathrm{~mm}$ choline chloride minus $\mathrm{Ca}^{2+}$.

1980). A salient feature of the effect of ouabain on the heart is that it typically occurs at concentrations lower than those required to inhibit the cardiac $\mathrm{Na}, \mathrm{K}$-ATPase in vitro, a phenomenon that has resulted in much debate about the mechanism of ouabain inotropy. Lechat et al. (1983) have presented evidence that the inotropy seen at very low concentrations of ouabain in the guinea pig atrium may be due to the effects of autonomic transmitters. The low affinity form of the Na,K-ATPase is expressed in cultured sympathetic neurons of the rat (Sweadner, 1979); thus, it is not surprising that high concentrations of ouabain are required to elicit norepinephrine release here. However, the release of $\left[{ }^{3} \mathrm{H}\right]$ norepinephrine required a concentration of ouabain that is sufficient to cause nearly complete inhibition of even the low affinity Na,K-ATPase, which makes it unlikely that ouabain-elicited transmitter release can account for inotropy in the rat. The paradox could be explained if the sensitive cell, a sympathetic neuron or a cardiac cell, expressed the high affinity form of the catalytic subunit of the Na,K-ATPase in vivo. Alternatively, the inotropic effect could result not from increased norepinephrine release, but from reduced norepinephrine reuptake; it would be of interest to contrast the ouabain concentration dependencies for the inhibition of norepinephrine uptake and the stimulation of norepinephrine release.

The brain contains both forms of the Na,K-ATPase, whereas the forms expressed in most neurons innervating peripheral tissues is not known. It is possible that an apparent discrepancy in the sensitivities of different transmitters to release by ouabain is due to the use of a concentration of ouabain that is not sufficient to fully inhibit the low affinity form of the Na,K-ATPase. Raiteri et al. (1977), for example, found the release of norepinephrine from rat brain synaptosomes to be very insensitive to $10^{-4} \mathrm{M}$ ouabain, whereas Raiteri et al. (1979) found the release of dopamine to be very sensitive in the same species and under similar experimental conditions. These invesligators presented evidence that both tranismitters leave the cell by plasma membrane carriers. Unless there are fundamental differences in the properties of the norepinephrine and dopamine carriers, one would predict from these results that norepinephrine should be found in cells expressing the low affinity form of the $\mathrm{Na}, \mathrm{K}$-ATPase, and dopamine should be found in cells expressing the high affinity form. O'Fallon et al. (1981) found striking regional variations in the release of several transmitters from rat brain slices in response to $10^{-5} \mathrm{M}$ ouabain, a concentration that would be expected to inhibit only the high affinity form of the Na,K-ATPase; the use of a concentration of ouabain high enough to inhibit the low affinity form as well might have given different results.

Summary. To evaluate the biological significance of ouabainelicited transmitter release, we would like to know if it mimics any naturally occurring process, such as changes in intracellular ion concentrations following repetitive nerve activity or neuromodulator action. What remains to be determined is whether intracellular $\mathrm{Na}^{+}$ ever rises, even transiently, to levels comparable to those achieved after inhibition of the Na,K-ATPase. If they do, then reversal of the $\mathrm{Na}^{+}$-dependent carrier may be a normal mechanism of transmitter release. If they do not, then ouabain-elicited release may be of relevance only to cardiac glycoside toxicity and to ischemia.

\section{References}

Baker, P. F., and A. C. Crawford (1975) A note of the mechanism by which inhibitors of the sodium pump accelerate spontaneous release of transmitter from motor nerve terminals. J. Physiol. (Lond.) 247: 209-226.

Banks, P. (1967) The effect of ouabain on the secretion of catecholamines and on the intracellular concentration of potassium. J. Physiol. (Lond.) 193: $631-637$.

Birks, R. I. (1962) The effects of a cardiac glycoside on subcellular structures within nerve cells and their processes in sympathetic ganglia and skeletal muscle. Can. J. Biochem. Physiol. 40: 303-315.

Birks, R. I. (1963) The role of sodium ions in the metabolism of acetylcholine. Can. J. Biochem. Physiol. 41: 2573-2597.

Birks, R. I., and M. W. Cohen (1968) The action of sodium pump inhibitors on neuromuscular transmission. Proc. R. Soc. Lond. (Biol.) 170: 381-399.

Blaszkowski, T. P., and D. F. Bogdanski (1972) Evidence for sodiumdependent outward transport of the ${ }^{3} \mathrm{H}$-norepinephrine mobilized by calcium at the adrenergic synapse. Inhibition of transport by desipramine. Life Sci. 11: 867-876.

Blaustein, M. P. (1975) Effects of potassium, veratridine, and scorpion venom on calcium accumulation and transmitter release by nerve terminals in vitro. J. Physiol. (Lond.) 247: 617-655.

Blaustein, M. P., E. M. Johnson, Jr., and P. Needleman (1972) Calciumdependent norepinephrine release from presynaptic nerve endings in vitro. Proc. Natl. Acad. Sci. U. S. A. 69: 2237-2240.

Branisteanu, D. D., B. Proca, and I. D. Haulicha (1979) Dual action of ouabain on transmitter release at neuromuscular junctions of the frog. J. Pharmacol. Exp. Ther. 209: 31-36.

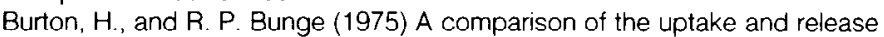
of $\left[{ }^{3} \mathrm{H}\right]$-norepinephrine in rat autonomic and sensory ganglia in tissue culture. Brain Res. 97: 157-162.

Carafoli, E. (1982) The transport of calcium across the inner membrane of mitochondria. in Membrane Transport of Calcium, E. Carafoli, ed., po. 109-139, Academic Press, Inc., New York.

Collard, K. J., and S. R. Williams (1981) The effect of ouabain on the release of 5-hydroxytryptamine from superfused synaptosomes. Biochem. Soc. Trans. 9: 109-110

Elmqvist, D., and D. S. Feldman (1965) Effects of sodium pump inhibitors on spontaneous acetylcholine release at the neuromuscular junction. $\mathrm{J}$. Physiol. (Lond.) 181: 498-505.

Furshpan, E. J., P. R. MacLeish, P. H. O'Lague, and D. D. Potter (1976) Chemical transmission between rat sympathetic neurons and cardiac myocytes developing in microcultures: Fvidence for cholinergic, adrenergic, and dual-function neurons. Proc. Natl. Acad. Sci. U. S. A. 73: 42254229.

Garcia, A. G., M. Hernandez, J. F. Horga, and P. Sanches Garcia (1980) On the release of catecholamines and dopamine- $\beta$-hydroxylase evoked by ouabain in the perfused cat adrenal gland. Br. J. Pharmacol. 68: 571-583.

Gillis, R. A., and J. A. Quest (1980) The role of the nervous system in the cardiovascular effects of digitalis. Pharmacol. Rev. 31: 19-97.

Graf, E., and J. T. Penniston (1981) CaATP: The substrate, at low ATP concentrations, of $\mathrm{Ca}^{2+} \mathrm{ATPase}$ from human erythrocyle membranes. J. Biol. Chem. 256: 1587-1592. 
Hawrot, E., and P. H. Patterson (1979) Long-term culture of dissociated sympathetic neurons. Methods Enzymol. 58: 574-584.

Iversen, L. L. (1975) Uptake processes for biogenic amines. In Handbook of Psychopharmacology, I. I. Iversen, S. D. Iversen, and S. H. Snyder, eds. Vol. 3, pp. 381-442, Plenum Press, New York.

Kenigsberg, R. L., and J. M. Trifaro (1980) Presence of a high affinity uptake system for catecholamines in cultured bovine adrenal chromaffin cells. Neuroscience 5: 1547-1556.

Landis, S. C. (1976) Rat sympathetic neurons and cardiac myocytes developing in microcultures: Correlation of the fine structure of endings with neurotransmitter function in single neurons. Proc. Natt. Acad. Sci. U. S. A. 73: 4220-4224.

Lastowecka, A., and J. M. Trifaro (1974) The effect of sodium and calcium ions of the release of catecholamines from the adrenal medulla: Sodium deprivation induces release by exocytosis in the absence of extracellular calcium. J. Physiol. (Lond.) 236: 681-705

Lechat, P., C. R. Malloy, and T. W. Smith (1983) Active transport and inotropic state in guinea pig left atrium. Circ. Res. 52: 411-422.

Lee, C-M., and S. H. Snyder (1981) Norepinephrine neuronal uptake binding sites in rat brain membranes labeled with $\left[{ }^{3} \mathrm{H}\right]$ desipramine. Proc. Natl. Acad. Sci. U. S. A. 78: 5250-5254

Levi, G., and M. Raiteri (1978) Modulation of $\gamma$-aminobutyric acid transport in nerve endings: Role of extracellular $\gamma$-aminobutyric acid and of cationic fluxes. Proc. Natl. Acad. Sci. U. S. A. 75: 2981-2985.

Liang, N. Y., and C. O. Rutledge (1982) Evidence for carrier-mediated efflux of dopamine from corpus striatum. Biochem. Pharmacol. 31: 2479-2484

Lorenz, R. R., D. A. Powis, P. M. Vanhoutte, J. T. Shephard (1980) The effects of acetylstrophanthidin and ouabain on the sympathetic adrenergic neuroeffector junction in canine vascular smooth muscle. Circ. Res. 47 845-854

Meyer, E. M., and J. R. Cooper (1981) Correlations between $\mathrm{Na}^{+}-\mathrm{K}^{+}$ATPase activity and acetylcholine release in rat cortical synaptosomes. J. Neurochem. 36: 467-475.

Minchin, M. C. W. (1980) Veratrum alkaloids as transmitter-releasing agents J. Neurosci. Methods 2: 111-121.

Mulder, A. H., W. B. Van den Berg, and J. C. Stoof (1975) Calcium-dependent release of radiolabeled catecholamines and serotonin from rat brain synaptosomes in a superfusion system. Brain Res. 99: 419-424

Nakazato, Y., A. Ohga, and Y. Onoda (1978) The effect of ouabain on noradrenaline outpul from peripheral adrentergic neurones of isolated guinea pig vas deferens. J. Physiol. (Lond.) 278: 45-54.

Nishimura, S., M. Sorimachi, and K. Yamagami (1981) Exocytotic secretion of catecholamines from the cat adrenal medulla by sodium deprivation: Involvement of calcium influx mechanism. Br. J. Pharmacol. 72: 305-317.

O'Fallon, J. V., R. W. Brosemer, and J. W. Harding (1981) The $\mathrm{Na}^{+}, \mathrm{K}^{+}$ ATPase: A plausible trigger for voltage-independent release of cytoplasmic neurotransmitters. J. Neurochem. 36: 369-378.

O'Lague, P. H., D. D. Potter, and E. J. Furshpan (1978) Studies on rat sympathetic neurons developing in cell culture. I. Growth characteristics and electrophysiological properties. Dev. Biol. 67: 384-403.

Palaty, $V$. (1981) Release of noradrenaline from the rat tail artery induced by inhibition of the sodium pump in calcium-free solution. Can. J. Physiol. Pharmacol. 59: 347-350.

Paton, D. M. (1973) Mechanism of efflux of noradrenaline from adrenergic nerves in rabbit atria. Br. J. Pharmacol. 49: 614-627.

Patterson, P. H. (1978) Environmental determination of autonomic neurotransmitter function. Annu. Rev. Neurosci. 1: 1-17.

Patterson, P. H., L. F. Reichardt, and L. L. Y. Chun (1976) Biochemical studies on the development of primary sympathetic neurons in cell culture. Cold Spring Harbor Symp. Quant. Biol. 40: 389-397.

Pocock, G. (1983a) lonic and metabolic requirements for stimulation of secretion by ouabain in bovine adrenal medullary cells. Mol. Pharmacol. 23: $671-680$

Pocock, G. (1983b) lon movements in isolated bovine adrenal medullary cells treated with ouabain. Mol. Pharmacol. 23: 681-697

Powis, D. A. (1983) Cardiac glycosides and autonomic neurotransmission. J. Auton. Pharmacol. 3: 127-154

Pressman, B. C. (1976) Biological applications of ionophores. Annu. Rev. Biochem. 45: 501-530.

Pullman, M. E., H. S. Penefsky, A. Datta, and E. Racker (1960) Partial resolution of the enzymes catalyzing oxidative phosphorylation. I. Purification and properties of soluble, dinitrophenol-stimulated adenosine triphosphatase. J. Biol. Chem. 235: 3322-3329.

Raiteri, M., and G. Levi (1978) Release mecharismss Ior catecholamines and serotonin in synaptosomes. Rev. Neurosci. 3: 77-130.

Raiteri, M., R. del Carmine, A. Bertollini, and G. Levi (1977) Effect of desmethylimipramine on the release of $\left[{ }^{3} \mathrm{H}\right]$-norepinephrine induced by various agents in hypothalamic synaptosomes. Mol. Pharmacol. 13: 746758.

Raiteri, M., F. Cerrito, A. M. Cervoni, and G. Levi (1979) Dopamine can be released by two mechanisms differentially affected by the dopamine transport inhibitor nomifensine. J. Pharmacol. Exp. Ther. 208: 195-202

Role, L. W., and R. L. Perlman (1983) Catecholamine uptake into isolated adrenal chromaffin cells: Inhibition of uptake by acetylcholine. Neuroscience 10: 987-996.

Rutledge, C. O. (1978) Effect of metabolic inhibitors and ouabain on amphetamine- and potassium-induced release of biogenic amines from isolated brain tissue. Biochem. Pharmacol. 27: 511-516.

Schwartz, A., G. E. Lindenmayer, and J. C. Allen (1975) The Na,K-ATPase: Pharmacological, physiological, and biochemical aspects. Pharmacol. Rev. 27: $3-134$

Schwartz, E. A. (1982) Calcium-independent release of GABA from isolated horizontal cells of the toad retina. J. Physiol. (Lond.) 323: 211-217.

Specht, S. C., and K. J. Sweadner (1984) Two different Na,K-ATPases in the optic nerve: Cells of origin and axonal transport. Proc. Natl. Acad. Sci. U. S. A. 81 : $1234-1238$.

Sweadner, K. J. (1979) Two molecular forms of $\left(\mathrm{Na}^{+}+\mathrm{K}^{+}\right)$-stimulated ATPase in brain. Separation, and difference in affinity for strophanthidin. J. Biol. Chem. 254: 6060-6067.

Sweadner, K. J. (1983) Post-translational modification and evoked release of two large surface proteins of sympathetic neurons. J. Neurosci. 3: 25042517

Vizi, E. S. (1972) Stimulation by inhibition of $\left(\mathrm{Na}^{+}-\mathrm{K}^{+}-\mathrm{Mg}^{2+}\right)$-activated ATPase of acetylcholine release in cortical stices from rat brain. J. Physiol. (Lond.) 226: $95-117$

Vizi, E. S., and F. Vyskocil (1979) Changes in total and quantal release of acetylcholine in the mouse diaphragm during activation and inhibition of membrane ATPase. J. Physiol. (Lond.) 286: 1-14.

Vizi, E. S., T. Torok, A. Seregi, P. Serfozo, and V. Adam-Vizi (1982) Na,K activated ATPase and the release of acetylcholine and noradrenaline. J. Physiol. (Paris) 78: 399-406.

Vyas, S. and R. M. Marchbanks (1981) The effect of ouabain on the release of $\left[{ }^{14} \mathrm{C}\right]$-acetylcholine and other substances from synaptosomes. J. Neurochem. 37: 1467-1474.

Wakade, A. R. (1981) Facilitation of secretion of catecholamines from rat and guinea pig adrenal glands in potassium-free medium or after ouabain. J. Physiol. (Lond.) 313: 481 498.

Yazulla, S., and J. Kleinschmidt (1983) Carrier-mediated release of GABA from retinal horizontal cells. Brain Res. 263: 63-75. 